\title{
Prevalence of otorhinolaryngologic diagnoses in the pediatric emergency room
}

\author{
Luiz Gabriel Signorelli', Elaine de Abreu Mendes².
}

1) Physician and Dentist. Third-year Resident in Otorhinolaryngology

2) Doctorate in Medical Sciences. Universidade de São Paulo, Head of the Department of Otorhinolaryngology, Hospital Universitário São Francisco.

Institution: Hospital Universitário São Francisco da Divina Providência de Deus.

Campinas / SP - Brazil.

Mailing address: Luiz Gabriel Signorelli - Rua Américo Ferreira de Camargo Filho, 539 - Sousas - Campinas / SP - Brazil - Zip code: 13106-134 - Telephone: (+55 19) 3256-5973 - E-mail: lgsignorelli@ hotmail.com

Article received in July 23, 2012. Article accepted in September 11, 2012

\section{SUMMARY}

Introduction: Fever and pain, which are very common in ear, nose, and throat pathologies, are among the most frequent complaints recorded during emergency room pediatric patient treatment. Most of time, the pediatricians are called on to evaluate otorhinolaryngology disorders that requires specialist assessment.

Aim: To determine the prevalence of otorhinolaryngologic diagnoses in a pediatric population in a reference hospital in the city of Itatiba, São Paulo.

Methods: We evaluated 2,054 pediatric patients (age range, 0-12 years, 11 months) in this descriptive, transversal observational (survey) study. Data collection was performed by a single observer during 103 night shifts (07:00 p.m. to 07:00 a.m.) between January and December 2011, and included documentation of the main diagnosis, and patient age and sex. The ethics committee and research institution approved study. Patients were divided into 2 groups based on diagnosis: Group A otorhinolaryngology disease and Group B included diagnoses not contained in Group A.

Results: Of the total enrolled patients, 52.2\% corresponded to Group A and 47.8\% to Group B; 51.9\% were male and 48.1\% were female. The average age was 4.5 years (Group A, 3.93 years; Group B, 5.03 years). We compared the prevalence of the diagnostic hypotheses of the 2 groups.

Conclusion: A large number of patients sought treatment at pediatric emergency rooms for otorhinolaryngologic diagnoses. Keywords: emergency medical services, pediatrics, otorhinolaryngologic diagnoses.

\section{INTRODUCTION}

Symptoms such as fever and pain are among the most frequent complaints recorded during emergency room (ER) pediatric patient treatment (1). Notably, these symptoms are very common in ear, nose, and throat (ENT) pathologies (2); large ENT emergency centers are an important part of emergency care. An estimated 25$40 \%$ of general medical practice relates to ENT problems $(3,4)$.

The presence of on-call ENT specialists is uncommon in child emergency hospitals in the state of São Paulo. For this reason, the pediatricians that are on duty are called on to provide these services, including in some instances, evaluating otorhinolaryngology disorders that require specialist assessment. A discrepancy was noted between pediatricians and otorhinolaryngologists with regard to the diagnosis and treatment of upper respiratory infections (5).
Few epidemiological studies have been conducted in pediatric emergency departments with focus on otorhinolaryngology care. Some studies have noted frequent visits to emergency departments that specialize in otorhinolaryngology (6-10), which exist only in large centers.

Hospital Santa Casa de Misericordia de Itatiba provides the only public emergency service in the city of Itatiba; in 2011, it provided treatment to 32,901 pediatric patients: $72.4 \%$ of the visits were through public service and only one other pediatric service in the city offered treatment through insurance. Itatiba is located in São Paulo, $80 \mathrm{~km}$ from the capital. It has a population of 101,471 (11) and its human development index level is $0.828,38$ th in the state. Its economy is industrial-based (12) and is part of the Jundiaí-DRS VII region (Campinas).

The objective of this study was to detect the prevalence of otorhinolaryngologic diagnoses in a pediatric population in a reference hospital in Itatiba City, São Paulo. 


\section{Methods}

We evaluated 2,054 pediatric patients (age range, 0-12 years, 11 months) who voluntarily sought emergency room treatment, arrived by ambulance, were transferred from other services, were under observation, and/or had been present from the day shift (07:00 a.m. to 07:00 p.m.).

We excluded patients who voluntarily opted not to receive treatment even though a patient chart had been prepared for them

The enrolled patients were from both the public health care system and the private health sector.

The study was descriptive, transversal, and observational (survey). Data collection was performed during 103 night shifts (07:00 p.m. to 07:00 a.m.) between January and December 2011. The main diagnosis, and patient age and sex were recorded. The ethics committee and research institution approved the study.

A single observer performed the data collection. The first 6 months of the study sessions were shared with another attending physician, whose patients were not included in the study. The average attendance was 13 patients per shift during the first 6 months and 26 during the last 6 month.

Patients were divided into 2 groups based on diagnosis: Group A otorhinolaryngologic diagnoses, and Group B included patients with diagnoses other than those included in Group A.

Group A patients were grouped based on diagnostic hypotheses involving the ear, nose, larynx-pharynx-mouth (LPM), nonspecific upper airway infections (UAI), or others (e.g., ALTE, tracheostomy management, dental avulsion, toothache, dacryocystitis, facial herpes, or reactive lymphadenitis).

A patient was considered to have nonspecific UAI if symptoms were recent ( 48 hours) and likely due to a virus, if the patient expressed vague complaints regarding the upper airways, if the patient exhibited a low fever, and if a focus of infection was not evident yet.

Group B patients were grouped based on diagnostic hypotheses of the gastrointestinal tract, lower respiratory tract, urinary tract, skin and appendages, healthy patients (eutrophic), other trauma, other diseases of the eye and appendages, diseases of the central nervous system, and others (e.g., exogenous intoxication, undiagnosed fever, purpura, arthralgia, suspected leptospirosis, suspected sexual abuse, hypoglycemia, cardiopulmonary arrest reversed).

\section{RESULTS}

Of the 2,054 admissions to the pediatric ER, 1,072 (52.2\%) corresponded to Group A and $982(47.8 \%)$ to Group B (Chart 1).The sex breakdown was $51.9 \%$ male and $48.1 \%$ female.

With regard to age, the largest age group was patients aged under 1 year (15.3\%), followed closely by patients 1 year of age (15.0\%). The overall mean patient age was 4.5 years with a median and mode of 3 and $<1$ year, respectively. The average age was 3.93 for Group A, and the median and mode were 3 and 1 year, respectively. For Group B, the average age was 5.03 years, and the median and mode were 5 and $<1$ year, respectively.

We compared the prevalence of ENT (Group A) and non-ENT (Group B) diagnostic hypotheses based on the patients' ages (Chart 2).

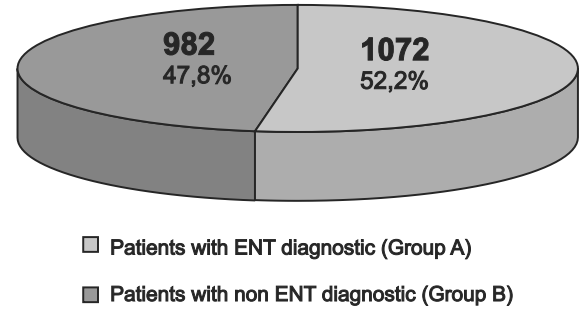

Chart 1. Relationship between patients with ENT and nonENT diagnoses who were treated at the pediatric emergency room during night shifts in 2011 at Hospital Santa Casa de Misericordia Itatiba.

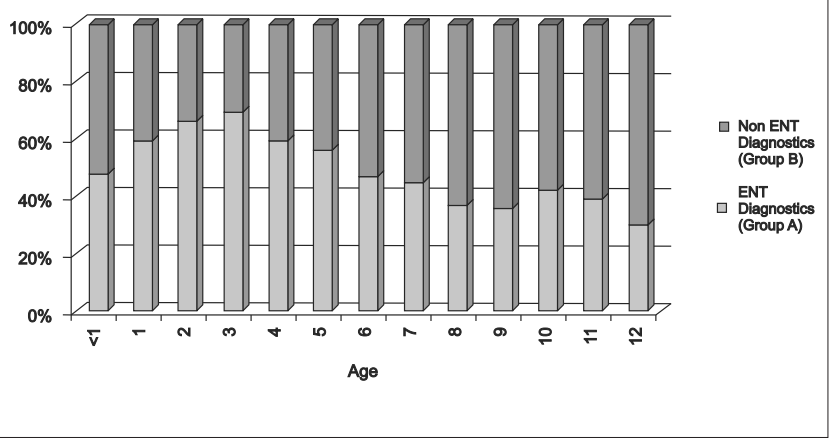

Chart 2. Relationship between patients with ENT and nonENT diagnoses based on age when they were treated at the emergency room during night shifts in 2011 at Hospital Santa Casa de Misericordia Itatiba. 
Among Group A patients, nonspecific infections of the upper airways were predominant (77.2\%), followed by otology background (8.7\%), LPM (7.2\%), nasal (3.4\%), and others (3.4\%) (Table 1).

In Group B patients, there was a predominance of the gastrointestinal tract background (29.0\%), followed by trauma (20.9\%), healthy patients(13.3\%), diseases of the skin and appendages (11.2\%), lower respiratory tract (7.3\%), other (5.4\%), urinary tract (4.4\%), eyes and appendages (4.4\%), and diseases related to the central nervous system (4.1\%) (Table 2).

The number of admissions served per shift increased during June and October for Group A. The same was not observed for Group B.

\section{DISCUSSION}

Increasingly, urgent emergency services are called upon to meet the shortage of basic medical care, which is associated with ineffective public policy measures and hospital-envisioned population. The same is true for specialized outpatient care, where high demand forces patients to seek emergency treatment as an alternative (13).

Epidemiological studies on emergency services and pediatric emergencies are rare in the literature and mostly focus on traumatology.

Otorhinolaryngological emergency studies have been conducted for services specializing in this area. Thus, it is expected that studies on these services will reveal epidemiological differences related to our study because it is a specialized service, the records for nonspecific infections of the upper airways are not routinely included, and space needs to be reserved for these patients in pediatric ERs.

Studies that relate complaints regarding the upper airways and other related otorhinolaryngology areas in a general pediatric ER were not found.

In our study, we found a high prevalence of otorhinolaryngologic diagnoses in the pediatric ER studied (52.2\%), and this presents another reason for the expansion and continuance of education otorhinolaryngology projects for pediatricians .

We also observed different average ages in the 2 groups: Group A patients (3.93 years) were younger than Group B patients ( 5.03 years).

From observation of Group A alone, we noted a significant difference between the most prevalent diagnosis
Table I. Number and percentage of diagnostic subtypes in Group A patients seen in the pediatric emergency room of Hospital Santa Casa de Misericordia Itatiba in 20 I I during night shifts.

\begin{tabular}{lcc}
\hline Diagnosedarea & $\mathrm{N}$ & $\%$ \\
\hline Upperairwayinfections & 828 & 77.2 \\
Ear & 93 & 8.7 \\
Larynx-pharynx-mouth & 77 & 7.2 \\
Nonspecific other & 38 & 3.5 \\
Nose & 36 & 3.4 \\
\hline Total & 1072 & 100 \\
\hline
\end{tabular}

Table 2. Number and percentage of diagnostic subtypes in Group B patients treated at the pediatric emergency room of Hospital Santa Casa de Misericordia Itatiba in 201 I during night shifts.

\begin{tabular}{lcc}
\hline Diagnosedarea & $\mathrm{N}$ & $\%$ \\
\hline Gastrointestinaltract & 285 & 29.0 \\
Othertrauma & 205 & 20.9 \\
Healthy patients & 13 I & 13.3 \\
Skinandappendages & 110 & 11.2 \\
Lower respiratorytract & 72 & 7.3 \\
Otherdiseases & 53 & 5.4 \\
Other diseases of the eye and appendages & 43 & 4.4 \\
Urinarytract & 43 & 4.4 \\
Diseases of the central nervous system & 40 & 4.1 \\
\hline Total & 982 & 100 \\
\hline
\end{tabular}

(nonspecific UAI, 77.2\%) and the second most prevalent diagnosis (ear disease, 8.7\%). We believe this difference stems from parents often taking their children to a pediatric emergency room following initial symptoms, which usually include fever, and sometimes the focus of infection has yet to appear (insufficient amount of time).

If we were to exclude Group A patients who exhibit signs of nonspecific UAI (parents usually seek treatment from a pediatric ER), we would discover a similar prevalence to studies of ENT ERs: mostly for otology complaints, followed by LPM and nasal complaints (6). SAHA et al. (7), however, detected a higher prevalence of laryngeal complaints in a specialized ER in India. This difference is possibly due to cultural peculiarities in that country, in which the rate of foreign body detection in the larynx and esophagus is very high.

Group B demonstrated a predominance of complaints related to the gastrointestinal tract because a large number of children develop acute gastroenterocolitis in some seasons. 
Group A demonstrated an increase in the number of consultations during June and October, which can be explained by the increased frequency of respiratory disease during periods of seasonal temperature changes.

\section{CONCLUSION}

A large number of patients seeking treatment in pediatric ERs receive otorhinolaryngologic diagnoses.

\section{REFERENCES}

1. Batistela S, Guerreiro NP, Rossetto EG. Os motivos de procura pelo Pronto-Socorro pediatrico de um Hospital Universitario referidos pelos pais ou responsaveis. Semina: Ciencias Biologicas e da Saude, Londrina. 2008;29(2):121130 .

2. Sanches-Alcon M, Morera C, Perez-Garrigues H. Anales ORL Iber-Amer. 1993;20(3):235-49.

3. Guerra AFM, Goncalves DU, Juste MC, Cortes W, Alves CRL, Lima TMA. Otorrinolaringologia Pediatrica no Sistema Público de Saúde de Belo Horizonte. Rev. Saúde Pública. 2007;41(5):719-25.

4. Mir N, Trilla A, Quinto LL, Molinero M, Asenjo M. Que papel tiene la otorrinolaringologia en La assistencia primaria? Un analisis da variacion en areas concretas. Acta Otorrinolaringol Esp. 2002,53:495-501.

5. Balbani APS, Montovani JC, CarvalhoLR. Faringotonsilites em criancas: visão de uma amostra de pediatras e otorrinolaringologistas. Rev Bras Otorrinolaringol. 2009;75(1):139-146.

6. Furtado PL, Nakanishi M, Rezende GL, Granjeiro RC, Oliveira TS. Análise clinico-epidemiologica do atendimento de pronto-socorro de otorrinolaringologia de um hospital terciario. BrazJ Otorhinolaryngol. 2011;7(4):426-31.

7. Saha S, Chandra S, Mondal PK, Das S, Mishara S, Rashid MA, et.al. Emergency otorhinolaryngological cases in medical college, Kolkata - A Statistical Analisis. Indian J Otolaryngol Head and Neck. 2005;57(3):219-25.

8. Rouke T, Passone P, Philpott C, Batle A. ENT cases seen at a local "walk-in centre". A one year review. J Laryngol Otol. 2009;123(3):339-42.

9. Balbani APS, Kii MA, AngelicoJr. FV, Sanchez TG, Voegels RL, Butugan O, Camara J. Atendimento para retirada de corpos estranhos de ouvido, nariz e faringe em criancas. Investigacoes researchs. Pediatria (Sao Paulo). 1998;20(1):814.

10. Obon JP, Esteban JR, Pueyo JL, Liesa RF, Garcia JM, Navarro JS, et al. Estudio de las urgencias externas otorrinolaringologicas en un hospital terciario. Acta Otorrinolaring Esp. 1995;46(4):298-304.

11. www.ibge.gov.br - Censo 2010.

12. www.itatiba.sp.gov.br

13. Rivero VP, Ugena ER, Yanes KT, Fuentes MA, Garcia MM, Ruiz GT. Anales ORL Iber-Amer. 2003;30(3):237-45. 